\title{
О ВЛИЯНИИ АГРОЭКОЛОГИЧЕСКИХ УСЛОВИЙ ВЛАЖНЫХ СУБТРОПИКОВ РОССИИ НА ПРОДУКЦИОННЫЙ ПОТЕНЦИАЛ Actinida deliciosa (kiwifruit) *
}

\author{
Т.Д. БЕСЕДИНА, Ц.В. ТУТБЕРИДЗЕ $~$ Н.С. КИСЕЛЕВА
}

Актинидия деликатесная (киви) характеризуется высокой пищевой и биологической ценностью. Культура успешно освоена в субтропических регионах планеты. Особенности климата влажных субтропиков России отразились на фенологических фазах развития растений актинидии. В период формирования плодов актинидии (июнь-сентябрь) культуру орошают в зависимости от количества выпадающих осадков и температурного режима. В настоящей работе в условиях влажных субтропиков России впервые установлено неравномерное распределение осадков по годам в фазу формирования плодов актинидии деликатесной в сочетании с дефицитом влагозапасов в почве. Мы предлагаем определять сроки полива актинидии на основании измерения концентрации клеточного сока в черешке листа, которая находится в тесной связи с влажностью почвы корнеобитаемого (0-60 см) слоя культуры. Цель работы - определить комплекс агроэкологических факторов, влияющих на влагообеспеченность и урожайность актинидии деликатесной в условиях влажных субтропиков России. Исследования выполняли в 2016-2020 годах на Адлерской опытной станции ФИЦ Всероссийского института генетических ресурсов растений им. Н.И. Вавилова (Краснодарский край) на посадках актинидии деликатесной Actinida deliciosa copта Hayward позднего срока созревания. Площадь агрофитоценоза составляла 5,5 га. Посадка 1988 года, размещение $5 \times 4$ м, формировка - трехъярусная пальметта. Фиксировали среднесуточную и максимальную температуру в динамике с мая по октябрь каждого года, а также распределение осадков (по данным http://www.pogodaiklimat.ru). Влажность почвы, взятой в 10-сантиметровых слоях по глубине корнеобитаемого слоя (0-60 см), определяли термостатно-весовым методом. Концентрацию клеточного сока (КKC, \%) в листьях измеряли с мая по сентябрь рефрактометрически у десяти растений по трем декадам каждого месяца. Учет урожая проводили с каждого учетного куста $(n=30)$ в трех повторностях. Каждый год отбирали по 100 ягод для определения средней массы одной ягоды. Погодные условия вегетационного периода по годам существенно различались, наблюдалось аномальное распределение осадков и экстремальные температуры (выше $30{ }^{\circ} \mathrm{C}$ ), влияющими на водный режим растений и урожайность. В мае-июне 2016-2020 годов оводненность тканей листа была высокой (ККС 4,96-5,25 \%), следовательно, в период бутонизации, цветения и завязывания плодов влагообеспеченность насаждений была оптимальная. В августе начинался активный рост плодов, шла закладка генеративных органов следующего года, но погодные условия характеризовались высокой солнечной инсоляцией и температурой выше $30{ }^{\circ} \mathrm{C}$, что усиливало физическое испарение влаги, при этом количество атмосферных осадков было минимальным. Хотя запасы влаги в почвенном профиле с мая по октябрь были оптимальными (показатели в интервале 80$90 \%$ от наименышей влагоемкости по всей глубине почвенного профиля), концентрация клеточного сока повышалась с середины сентября и в конце месяца превышала $10 \%$ при полном насыщении почвы влагой. Эти факторы окружающей среды и пик физиологических процессов создавали дефицит воды в листьях до показателя ККС выше 7 \%, который еще мог нивелироваться поливами. В конце августа или в начале сентября (в зависимости от погодных условий) ККС устойчиво поднимался выше 8 \% как без полива, так и при орошении. В этот период происходит перераспределение фракций воды из связанной в свободную экологически активную форму. Чем раныше начинался период перехода транспортного потока воды и ассимилятов в растениях актинидии от листьев к плодам, тем выше были их масса и урожай. Таким образом, показано, что во влажных субтропиках России изученные агроэкологические факторы в наибольшей степени влияют на водный режим растений и величину урожая A. deliciosa сорта Наyward в период формирования плодов (август-сентябрь).

Ключевые слова: актинидия (киви), сорт Наyward, водный режим, продуктивность, теплообеспеченность, влагообеспеченность, влажные субтропики.

Культура Actinidia deliciosa (A. Ghev.) C. Fliang \& A.R. Ferguson (kiwifruit) натурализована в мировом производстве с 1970 года. В 2019 году количество производимых плодов киви в мире достигло 4274870 т/год, а площадь насаждений составила свыше 268 тыс. га (1). В этой отрасли лиди-

\footnotetext{
* Работа проведена в рамках темы 0492-2021-0007 «Выявить фундаментальные механизмы адаптации сельскохозяйственных культур, декоративных растений и искусственно созданных биоценозов к стрессфакторам различной природы и изучить закономерности их проявления с целью разработки приемов стабилизации продукционного процесса и сохранения декоративности».
} 
руют Китай, Италия, Новая Зеландия, Иран и Чили (2). Культуру успешно освоили в субтропических регионах планеты, а ее промышленное возделывание приобрело важное значение из-за высокой пищевой и биологической ценности (3-5). Агроценоз актинидии деликатесной отличается длительностью плодоношения (40 лет и более). Например, насаждения киви на Адлерской опытной станции ВИР были заложены в 1988 году $(6,7)$.

Эта субтропическая плодово-ягодная культура содержит сухие вещества, сахара, кислоты, витамины, полифенолы, аминокислоты, ароматические и минеральные вещества и используется при производстве функциональных продуктов питания, имеющих огромное значение в профилактике заболеваний. Ягоды актинидии деликатесной служат природным концентратом поливитаминов и минеральных элементов и сохраняют свои ценные свойства в естественном состоянии до полугода (8-10).

В условиях Новой Зеландии, где была выведена культура киви, определены три важные детерминанты климата для ее возделывания: оптимальное охлаждение (температура $11{ }^{\circ} \mathrm{C}$ и ниже), 1100 градусо-дней выше $10{ }^{\circ} \mathrm{C}$ за вегетационный период и годовое количество осадков 1250 мм и более (11).

В Польше в северо-восточных районах изучали влияние температурных факторов и осадков на урожайность пяти сортов Actinidia argute (12). Наряду с климатическими факторами, важное значение имеют почвенные условия, включая физическое состояние и биологические свойства почв (содержание ферментов, микроэлементов и т.д.) (13). Начало вегетации обусловлено повышенным сокодвижением в стеблях и корнях растений. За считанные дни корни начинают извлекать воду из мест увлажнения (14). В Италии - одной из стран-лидеров по производству киви в насаждениях культуры оптимизируют режимы полива для полноценного развития растений и созревания плодов (15). Водообеспеченность растений - один из ключевых факторов, определяющих величину и качество урожая (16-18).

Особенности климата влажных субтропиков России отразились на фенологических фазах развития растений актинидии. С III декады декабря по II декаду февраля происходит дифференциация почек, в марте начинается вегетация, в апреле-мае - бутонизация и цветение. Формирование плодов длится до сентября, созревание - с октября по ноябрь в зависимости от сорта. Для актинидии, как и для субтропических культур, определена базисная сумма активных температур (более $10^{\circ} \mathrm{C}$ ) до $4000 \pm 100{ }^{\circ} \mathrm{C}(8)$.

Показана реакция растений актинидии на сроки полива в течение дня, влияющая на биологические показатели культуры (19). Исследователи отмечают более высокий градиент воды от стебля к плоду в полдень/ранний полдень, что способствует росту плодов, но несущественно (20). В Испании у плодовых культур изучали эффективность капельного орошения в сравнении с поливом (по влиянию на почву и растения) (21). Условия окружающей среды во второй половине дня усугубляются высокими температурами, солнечной инсоляцией, повышенной транспирационной активностью. У киви полив в это время улучшает влагообеспеченность почвы, усиливается газообмен листьев и приток продуктов ассимиляции к плодам $(22,23)$.

Из-за потепления климата сумма температур выше $10{ }^{\circ} \mathrm{C}$ за последние 20 лет во влажных субтропиках России стала варьировать от 4559 до $4870{ }^{\circ} \mathrm{C}$, тогда как ранее она составляла $3735-4258{ }^{\circ} \mathrm{C}(24,25)$. В период формирования плодов (июнь-сентябрь) актинидия деликатесная требует орошения в зависимости от количества выпадающих осадков и температурного режима. Если влагообеспеченность растений и, как следствие, оводненность тканей листа снижается, концентрация клеточного сока в листьях повышается (26). 
В настоящей работе впервые установлено неравномерное распределение осадков в фазу формирования плодов актинидии деликатесной по годам в условиях влажных субтропиков России в сочетании с дефицитом влагозапасов в почве. Мы впервые разработали и применили физиологический показатель (концентрация клеточного сока в черешке листа актинидии) для оперативного диагностирования и установления оптимального водного режима, способствующего повышению продуктивности актинидии деликатесной.

Цель работы - определить комплекс агроэкологических факторов, влияющих на влагообеспеченность и урожайность актинидии деликатесной в изменяющихся условиях влажных субтропиков России.

Методика. Исследования были выполнены в 2016-2020 годах на опытном участке Адлерской опытной станции ФИЦ Всероссийского института генетических ресурсов растений им. Н.И. Вавилова (Краснодарский край) на актинидии деликатесной (Actinidia deliciosa) сорта Хейворд (Науward) позднего срока созревания. Посадка 1988 года, размещение $5 \times 4$ м, формировка - трехъярусная пальметта; площадь агрофитоценоза составляла 5,5 га. Почва под культурой - аллювиальная луговая малогумусная. Содержание гумуса в слое 0-20 см - 5,67 \%, подвижного фосфора 48,16 мг/100 г почвы, подвижных соединений калия - 18,3 мг/100 г почвы, рНвод. 7,16-7,30. Способ орошения капельный. Схема опыта включала три режима предпорогового полива от НВ - 90, 80 и $70 \%$.

Фиксировали среднесуточную и максимальную температуру в динамике, с мая по октябрь каждого года, а также распределение осадков (по данным http://www.pogodaiklimat.ru).

Влажность почвы, взятой в 10-сантиметровых слоях по глубине корнеобитаемого слоя (0-60 см), определяли термостатно-весовым методом, используя сушильный шкаф 2В-151 («Одесский экспериментальный завод медицинской техники», Украина) и весы лабораторные электронные ВСЛТ300/3A Pioner («Ohaus Instruments (Shangha) Co., Ltd.», КНР). На рисунках она представлена как процент от наименьшей влагоемкости (НВ), характеризующей наибольшее количество воды, остающейся после обильного увлажнения и стекания ее излишков при отсутствии подпирающего действия грунтовых вод. Оптимальное содержание влаги в почве для актинидии деликатесной - 80 \% от НВ (26).

Концентрацию клеточного сока (ККС, \%) в черешках листьев определяли с мая по сентябрь рефрактометрическим методом у десяти растений по трем декадам каждого месяца $(26,27)$.

Урожай учитывали с каждого куста (общее число учетных кустов в одной повторности $n=10)$ в трех повторностях. Каждый год отбирали по 100 ягод для определения средней массы одной ягоды.

Статистическую обработку проводили по Б.А. Доспехову (28) в программах Microsoft Excel и Statistica 10 («StatSoft, Inc.», США). С использованием $F$-критерия Фишера выполняли корреляционный анализ взаимосвязи влажности почвы в корнеобитаемом слое с концентрацией клеточного сока в зависимости от режима капельного полива. Вычисляли средние значения $(M)$, стандартные ошибки средних ( \pm SEM) и коэффициенты вариации $(C v, \%)(28)$.

Результаты. Во влажных субтропиках России с учетом тепло- и влагообеспеченности выделено три агроклиматических района $(24,29,30)$. Два из них (I и II) по сумме температур > $10{ }^{\circ} \mathrm{C}$ (3800-4300 и 3600-3800 $\left.{ }^{\circ} \mathrm{C}\right)$ 
отвечают потребностям субтропических культур, но из-за регистрируемых абсолютных минимумов, достигающих $-14 \ldots-15{ }^{\circ} \mathrm{C}$ (I) и $-17 \ldots-18{ }^{\circ} \mathrm{C}$ (II), при размещении посадок культуры требуется учет микрорельефа. Сумма осадков за год по районам составляет соответственно 1600 и 2100 мм, продолжительность безморозного периода - 250-300 и 200-250 сут. При внедрении ГИС (географическая информационная система) в Сочинском национальном парке установлено, что влажный субтропический климат сохраняется до 300-400 м над уровнем моря. Для тропического и континентального климата характерны значительные колебания погодных факторов, усиливающиеся до аномальных значений.

Оптимальное размещение культур и системный анализ комплекса факторов, воздействующих на продуктивность агрофитоценоза, способствуют повышению продуктивного потенциала культуры. Один из приемов оптимизации условий в агрофитоценозе - капельное орошение (31-33). Оптимизация абиотических условий в агроценозах приводит к существенно большему по сравнению с естественными фитоценозами выходу хозяйственно ценной продукции с единицы площади (33).
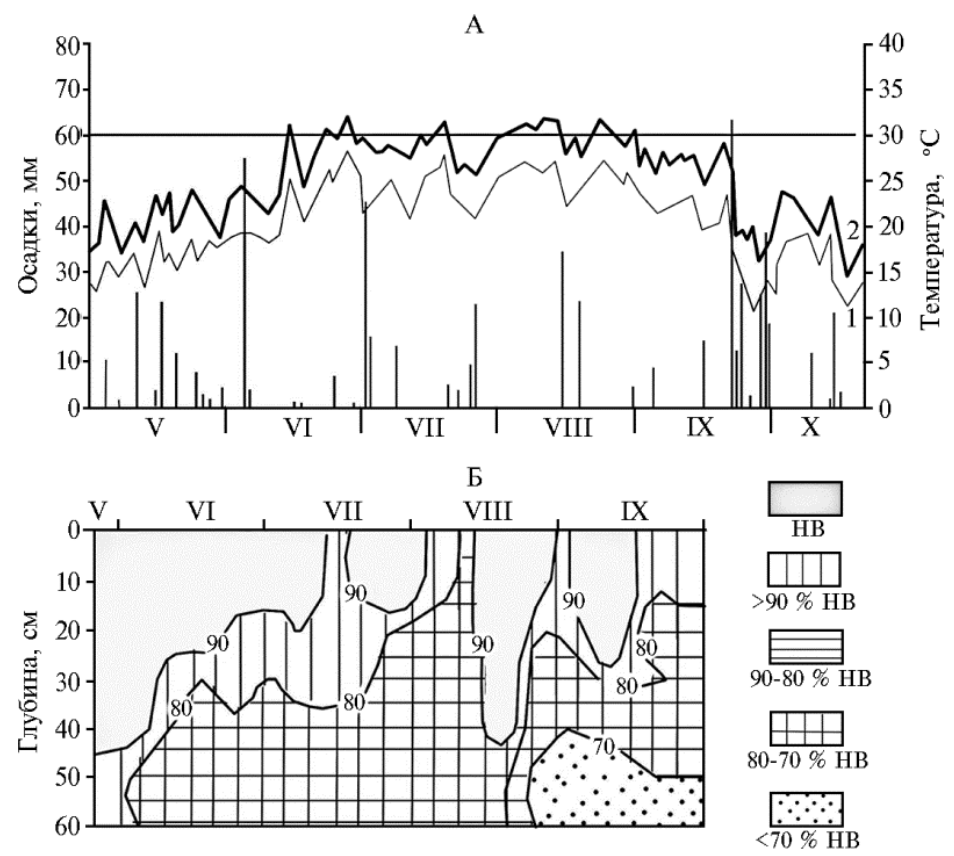

B

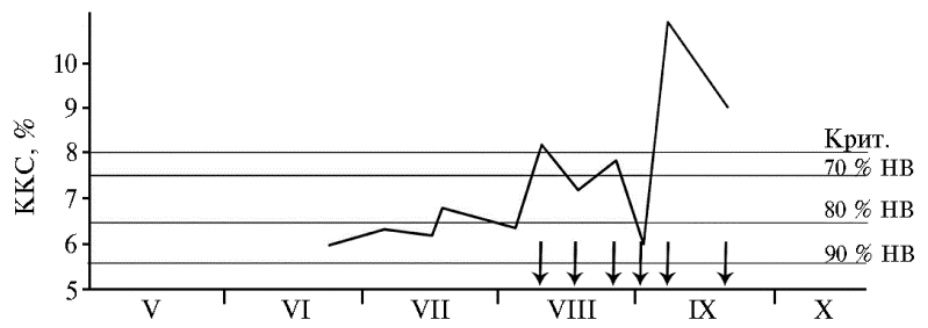

Рис. 1. Средняя (1) и максимальная (2) температура воздуха (А), запасы влаги в почве (\% от НВ) (Б) и концентрация клеточного сока $(\mathrm{KKC})(\mathrm{B})$ в черешках листьев актинидии деликатесной $A c$ tinidia deliciosa (A. Ghev.) C. Fliang \& A.R. Ferguson copта Наyward в условиях 2016 года (с мая по октябрь). НВ - наименьшая влагоемкость, Крит. - критическое значение влажности почвы. Годовое количество осадков 1682,0 мм, среднегодовая температура $14,7{ }^{\circ} \mathrm{C}$. Стрелками обозначены сроки полива (Адлерская опытная станция ВИР, Краснодарский край). 
В настоящей статье детальный и комплексный анализ влияния факторов внешней среды (погодных и почвенных) на динамику водного режима растений киви сорта Науward и их продуктивность приведен за 2016, 2019 и 2020 годы, которые различались по распределению осадков и температурному режиму.

На рисунке 1 представлены данные по компонентам системы погода-почва-водный режим растения в условиях 2016 года. Наблюдения за водным режимом растений актинидии в 2016 году с июня показали, что оводненность клеток листьев была высокой до 8 августа, но в конце I декады августа ККС превысил 8 \%, и только последующие поливы в августе способствовали его снижению (см. рис. 1).
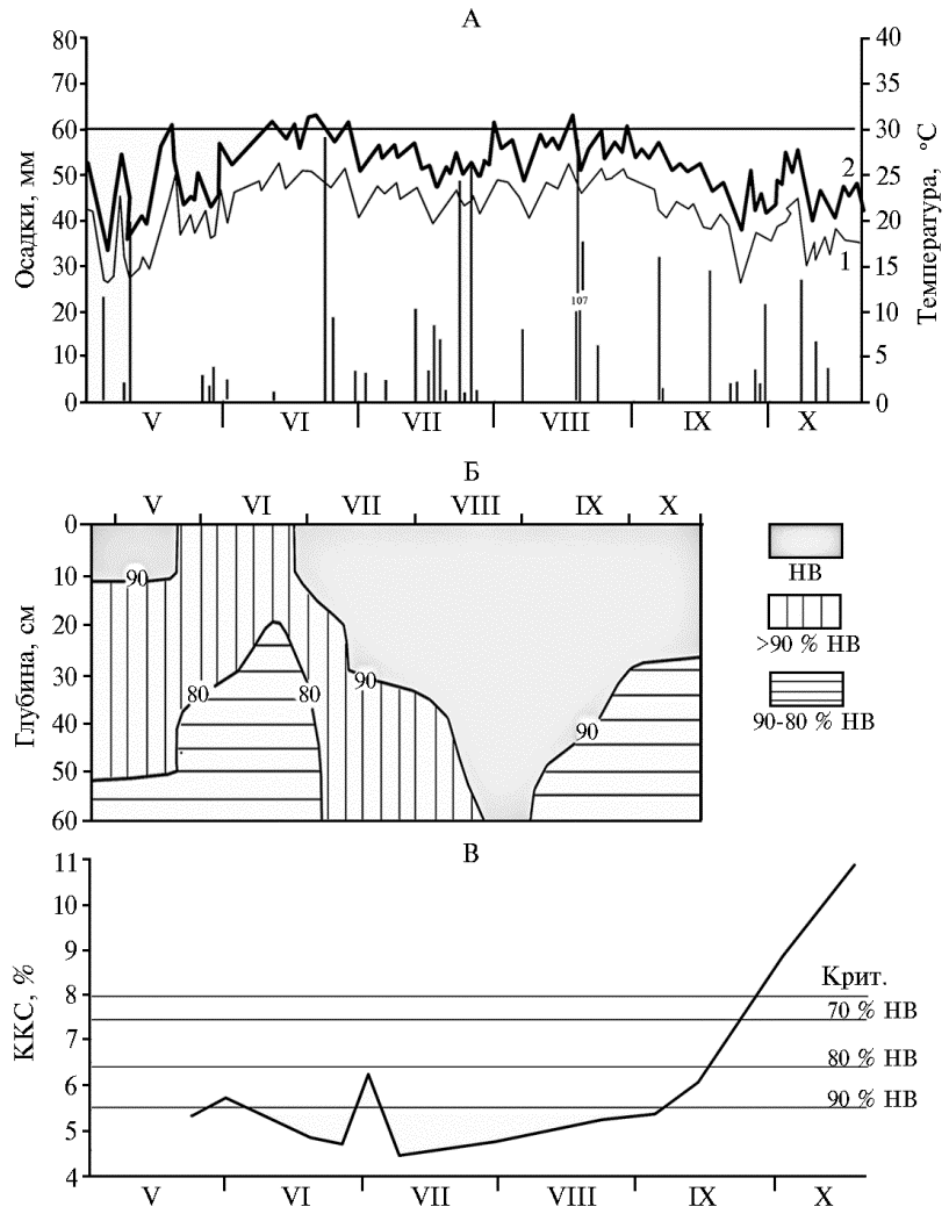

Рис. 2. Средняя (1) и максимальная (2) температура воздуха (А), запасы влаги в почве (\% от НВ) (Б) и концентрация клеточного сока (KKC) (B) в черешках листьев актинидии деликатесной $A c$ tinidia deliciosa (A. Ghev.) C. Fliang \& A.R. Ferguson copта Наyward в условиях 2019 года (с мая по октябрь). НВ - наименьшая влагоемкость, Крит. - критическое значение влажности почвы. Годовое количество осадков 1420,4 мм, среднегодовая температура $15,7{ }^{\circ} \mathrm{C}$ (Адлерская опытная станция ВИР, Краснодарский край).

Тепловой режим 2019 года характеризовался пониженными температурами и значительным выпадением осадков в период вегетации (рис. 2). Температура воздуха в июле снизилась на $0,8^{\circ} \mathrm{C}$ относительно среднемноголетних значений, тогда как и осадки превышали многолетние данные на $27 \%$, а в августе - на 37 \%. Максимальные температуры (выше $30^{\circ} \mathrm{C}$ ) были летом эпизодическими. Влагозапасы с мая по октябрь 2019 года характе- 
ризовались оптимальными показателями - 80-90 \% от НВ по всей глубине почвенного профиля, при этом полив не осуществлялся. Тем не менее концентрация клеточного сока стала повышаться с середины сентября, и в конце месяца была выше 10 \% при полном насыщении почвы влагой (см. рис. 2).

Сумма активных температур в наиболее сухом 2020 году достигла $5164^{\circ} \mathrm{C}$. Средняя годовая температура составила $15,8^{\circ} \mathrm{C}$, то есть увеличилась на $1,6{ }^{\circ} \mathrm{C}$ в сравнении со средним многолетним показателем. Максимальные температуры воздуха фиксировали с мая. За год выпало 1003 мм осадков, что составило 59 \% от нормы (1703 мм). Крайне засушливыми оказались июнь, август и сентябрь. Засуха усугублялась с марта до конца года (рис. 3). Напряженность водного режима в почвенном профиле прослеживалась с третьей декады августа в слое 30-60 см. Поливы в начале сентября оптимизировали влажностный режим в слое 50 см. Водный режим растений актинидии был оптимальным до I декады августа. Поливы в начале сентября не смогли улучшить водный режим культуры (см. рис. 3).

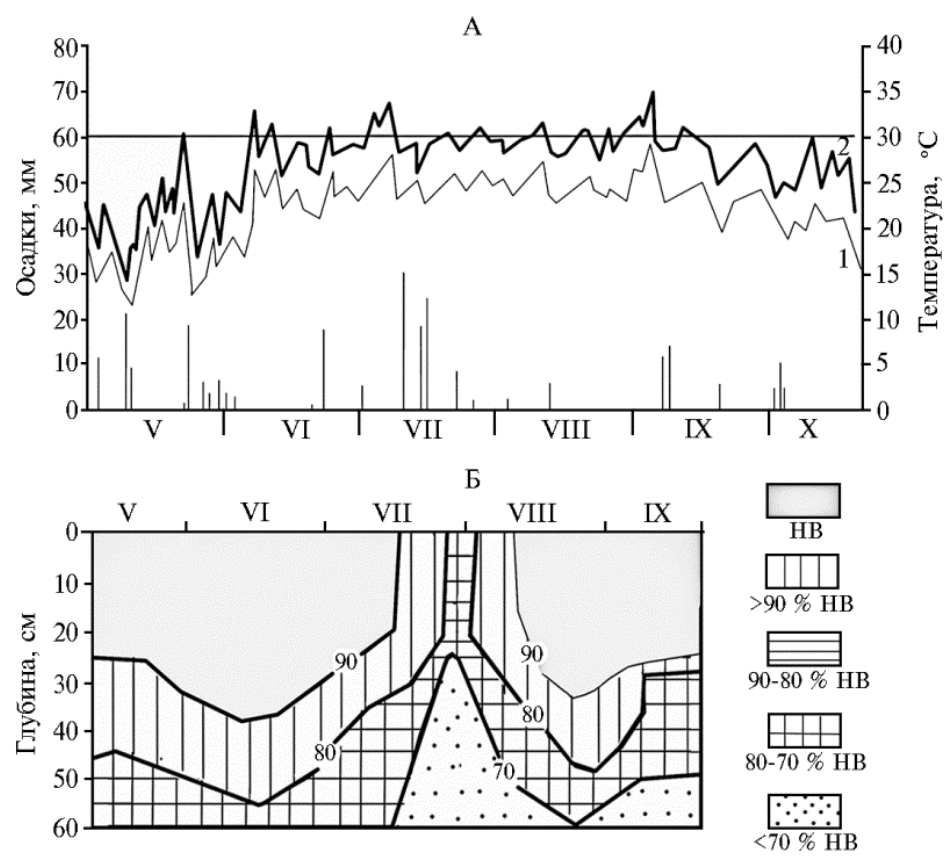

B

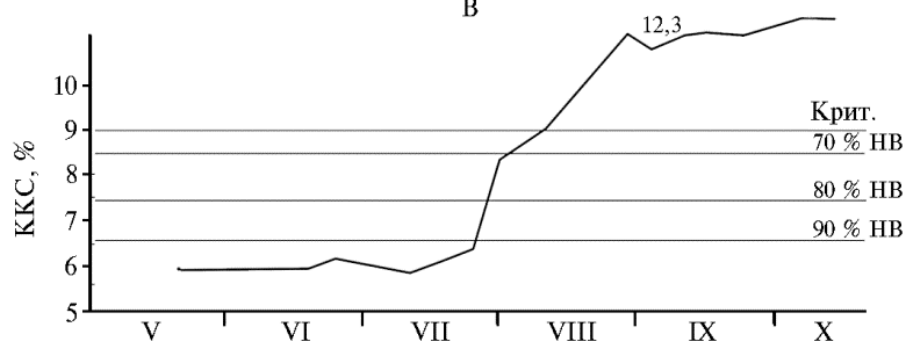

Рис. 3. Средняя (1) и максимальная (2) температура воздуха (А), запасы влаги в почве (\% от НВ) (Б) и концентрация клеточного сока $(\mathrm{KKC})(\mathrm{B})$ в черешках листьев актинидии деликатесной $A c$ tinidia deliciosa (A. Ghev.) C. Fliang \& A.R. Ferguson сорта Наyward в условиях 2020 года (с мая по октябрь). НВ - наименьшая влагоемкость, Крит. - критическое значение влажности почвы. Годовое количество осадков 1003,0 мм, среднегодовая температура $15,8{ }^{\circ} \mathrm{C}$ (Адлерская опытная станция ВИР, Краснодарский край).

Согласно данным, полученным в августе-сентябре 2016-2020 годов, концентрация клеточного сока в тканях листьев актинидии деликатесной в 
эти месяцы существенно увеличивалась (рис. 4, табл. 1).
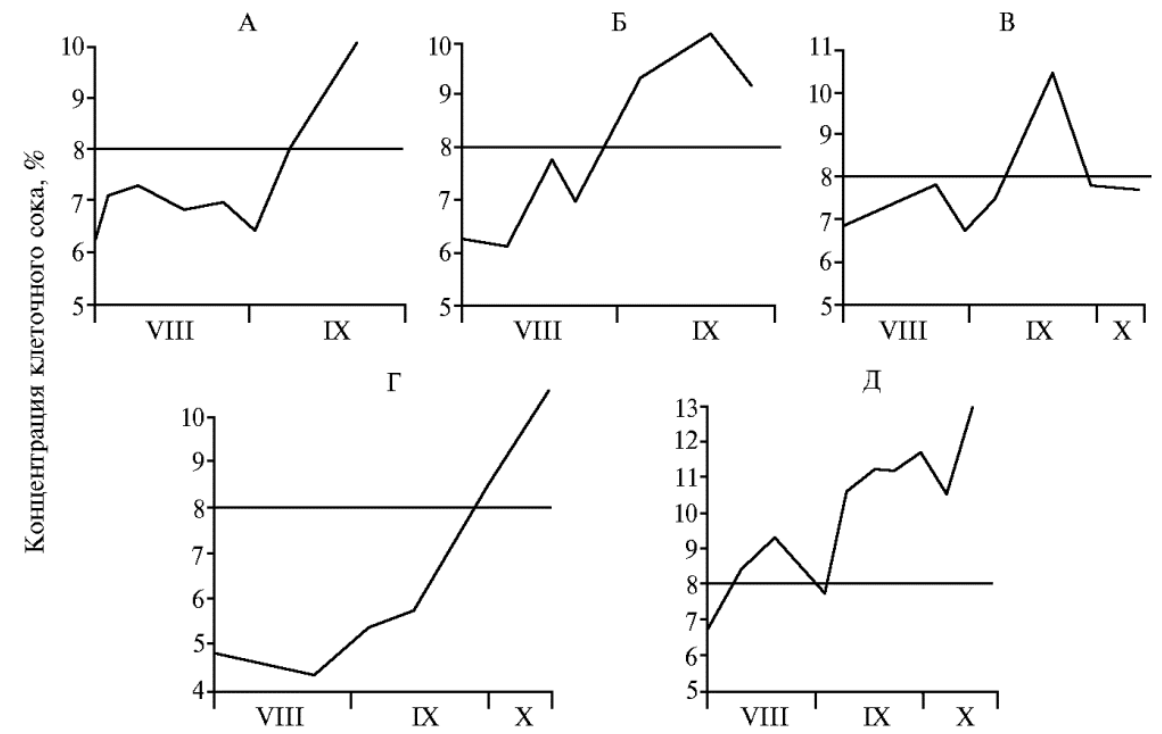

Рис. 4. Концентрация клеточного сока (KKC) в черешках листьев актинидии деликатесной Actinidia deliciosa (A. Ghev.) C. Fliang \& A.R. Ferguson copта Науward в период зрелости плодов (август-октябрь) в разные годы: А - 2016, Б - 2017, В - 2018, Г - 2019, Д - 2020; горизонтальная линия отмечает значение ККС, соответствующее критическому значению влагообеспеченности растений (Адлерская опытная станция ВИР, Краснодарский край).

1. Концентрация клеточного сока (КKC, \%) в черешках листьев актинидии деликатесной Actinidia deliciosa (A. Ghev.) C. Fliang \& A.R. Ferguson copта Hayward в сопоставлении с влажностью почвы в течение вегетации при выращивании в условиях влажных субтропиков России $(n=30, N=3, M \pm \mathrm{SEM}$, Адлерская опытная станция ВИР, Краснодарский край, 2016-2020 годы)

\begin{tabular}{l|c|c|c|c|c|c}
\hline \multirow{2}{*}{ Показатель } & \multicolumn{6}{c}{ Месяц } \\
\cline { 2 - 6 } & $\mathrm{V}$ & $\mathrm{VI}$ & $\mathrm{VII}$ & $\mathrm{VIII}$ & $\mathrm{IX}$ & $\mathrm{X}$ \\
\hline ККС, \% & $4,96 \pm 0,43$ & $5,25 \pm 0,09$ & $5,73 \pm 0,11$ & $7,14 \pm 0,17$ & $8,80 \pm 0,30$ & $9,87 \pm 0,35$ \\
$\mathrm{C}, \%$ & 8,8 & 11,3 & 16,5 & 17,8 & 23,6 & 15,5 \\
Влажность почвы, \% & 27,50 & 27,04 & 26,20 & 24,01 & 21,35 & 19,67
\end{tabular}

П р и м е ч а н и е. Для растений киви оптимальная влажность почвы $25 \%$ (80\% от НВ), влажность почвы, близкая к стрессу, - $22 \%$.

Корреляционный анализ взаимосвязи влажности почвы в корнеобитаемом слое актинидии деликатесной с концентрацией ККС в черешках листьев показал их тесную зависимость. Коэффициент корреляции $r$ был

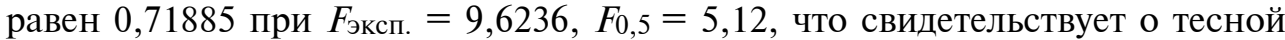
статистически значимой связи анализируемых факторов. Математическая модель имеет следующий вид: $\mathrm{У}=35,43-1,599 x$, где У - влажность почвы в слое $0-60$ см, \%; х - ККС, \%.

Высокая оводненность тканей листьев в мае-июле была характерна для фаз бутонизации, цветения, формирования завязей. Увеличение ККС в августе свыше $7,14 \pm 0,17$ \% совпадало с активным ростом плодов. В этот период происходит перераспределение фракций воды из связанной в свободную экологически активную форму (34). Содержание и соотношение форм воды в растении актинидии находится в тесной корреляционной зависимости от агроклиматических факторов во влажных субтропиках (35). Э.А. Гончарова (36) считает, что перераспределение форм воды и продуктов ассимиляции от листьев к плодам можно считать саморегуляцией растительным организмом транспортных потоков, имеющей значительную биологическую целесообразность в экстремальных условиях. Подобная саморегуляция, по 
нашему мнению, основанному на многолетних показателях изменения величины ККС в августе-сентябре, характерна и для актинидии деликатесной.

По величине урожая и массе плодов актинидии деликатесной сорта Hayward 2019 год был самым неблагоприятным, что объясняется высокими температурами $\left(>30^{\circ} \mathrm{C}\right)$ в фазу цветения (табл. 2). Влагообеспеченность в период созревания была оптимальной, поливы не проводились. Однако отток воды с ассимилятами произошел в конце сентября при наличии влаги в почве в пределах 90 \% от НВ и по всей глубине корнеобитаемого слоя.

2. Продуктивность актинидии деликатесной Actinidia deliciosa (A. Ghev.) C. Fliang \& A. R. Ferguson сорта Наyward при выращивании в условиях влажных субтропиков России $(n=30, N=3$, Адлерская опытная станция ВИР, Краснодарский край)

\begin{tabular}{l|c|c|c|c|c|c}
\hline \multicolumn{1}{c}{ Показатель } & \multicolumn{7}{c}{ Год } \\
\cline { 2 - 7 } & 2016 & 2017 & 2018 & 2019 & 2020 & $M \pm \mathrm{SEM}$ \\
\hline Урожай, кг с 1 куста & 7,3 & 8,6 & 23,5 & 4,6 & 8,6 & $10,5 \pm 3,3$ \\
Урожайность, ц/га & 32,8 & 38,7 & 105,8 & 20,7 & 38,7 & $47,3 \pm 6,4$ \\
От среднего урожая, \% & 69 & 82 & 224 & 44 & 82 & 100 \\
П р и м е ч н и е. Урожайность определяли на основании среднего урожая с куста в расчете на общее \\
число женских растений на 1 га (450 растений).
\end{tabular}

Минимальная масса плодов у сорта Hayward за 2016-2020 годы составила 87 г, максимальная - 135 г. В среднем такой размер плодов соответствует характеристикам сорта Наyward. Продуктивность сорта Hayward в 2020 году, который характеризовался острым недостатком влаги и ранним сроком (со II декады августа) оттока воды с продуктами метаболизма из листьев в плоды, составила около $82 \%$ от средней продуктивности за 5 лет. В благоприятном 2018 году (при капельном орошении) в условиях российских субтропиков получили урожайность 105,8 ц/га (см. табл. 2). Средняя урожайность киви в мире в 2018 году составила 160 ц/га (https://www.globaltrademag.com/global-kiwi-fruit-market-2019-new-zealand-and-italy-are-the-leadingexporters-of-kiwi-fruits/).

Возделывание актинидии деликатесной сорта Наyward в условиях Республики Абхазии показало сходную степень влияния агроклиматических факторов на урожайность культуры. В зависимости от продолжительности периода максимальных температур и количества выпавших осадков во время формирования плодов урожайность сорта Hayward в среднем составляла от 50 до 130 ц/га (9).

В странах Западной Европы ведется активная селекционная работа на различных видах актинидий с целью увеличения их продуктивности (37-39), качества плодов (40-42) и адаптивности к местным условиям (42, 43). Наибольшее внимание в исследованиях уделяется температурному фактору $(44,45)$.

В условиях влажных субтропиков России, как показал множественный корреляционный анализ, факторами, лимитирующими продуктивность актинидии деликатесной сорта Наyward, служат количество осадков и влажность воздуха в фазы цветения и созревания плодов (в фазу цветения - избыточное количество осадков, в фазу созревания - их дефицит). Количество осадков в фазу цветения - широко варьирующее и неуправляемое, вследствие чего этот период становится критическим. Дефицит осадков в период созревания можно нивелировать поливом.

Следует отметить, что и зонах традиционного возделывания (Новая Зеландия, Италия, Китай) вопросам влияния водного дефицита и способов и сроков полива на растения актинидии деликатесной, эффективности использования культурой водных ресурсов $(22,46,47)$ уделяется много внимания. Можно ожидать, что в условиях аридизации климата и дефицита 
водных ресурсов актуальность таких исследований будет возрастать. Время наступления водного стресса (в начале сезона или в более поздние сроки) влияет не только на урожайность, но и на содержание в плодах биологически значимых нутриентов (47). Поэтому полагают, что, выбирая сроки ирригации, можно целенаправленно изменять некоторые показатели качества плодов у актинидии деликатесной (47).

Поскольку эффективность полива актинидии деликатесной зависит от его сроков, важно располагать простым и доступным способом оценки водного статуса растений. Во многих исследованиях обсуждаются сроки, способы и влияние полива на продуктивность и качество плодов актинидии деликатесной $(23,26,43,47)$. Однако в имеющейся литературе мы не нашли данных о том, как определялось оптимальное для растения время полива. Концентрация клеточного сока в черешке листа, предложенная нами в качестве такого критерия, имеет существенное преимущество, так как, во-первых, это физиологический показатель, во-вторых, его легко определить рефрактометрическим методом. Установлена математическая модель тесной и значимой связи ККС в черешках листьев с влажностью почвы в корнеобитаемом слое (0-60 см). Выявлен оптимальный предпороговый срок полива для культуры $-80 \%$ от НВ.

Горный рельеф и пестрота почвенного покрова влажных субтропиков России, а также сортовая специфика актинидии деликатесной обусловливают возможности агроэкологического районирования этой молодой культуры на основе ее адаптивности. Изучение физиологического статуса актинидии деликатесной при выращивании на северных границах ареала промышленного возделывания представляет интерес для понимания генетического потенциала культуры. Важное значение для расширения ареала выращивания и повышения продуктивности актинидии деликатесной во влажных субтропиках России могут иметь разработки моделей агроэкосистемы культуры (48).

Таким образом, многолетнее изучение комплекса агроэкологических факторов влажных субтропиков России в фазу формирования плодов (август-сентябрь) культуры Actinidia deliciosa copта Наyward показало влияние количества атмосферных осадков, влажности почвы и концентрации клеточного сока в черешках листьев на продуктивность растений. Высокая оводненность тканей листьев в мае-июле была характерна для фаз бутонизации, цветения, формирования завязей. Увеличение ККС в августе свыше $7,14 \pm 0,17$ \% совпадало с активным ростом плодов. В этот период происходило перераспределение фракций воды из связанной в свободную, экологически активную форму. Чем раньше начинается период перехода транспортного потока воды и ассимилятов в растении актинидии от листьев к плодам, тем выше их масса и величина урожая. Увеличение ККС выше 8 \% свидетельствует о полном техническом созревании плодов актинидии деликатесной. Определены параметры влагообеспеченности культуры по показателям ККС от 5 до 8 \%. Предложен экспресс-метод рефрактометрического измерения концентрации клеточного сока в черешках листьев актинидии деликатесной. Метод позволяет оперативно и надежно определять сроки полива растений актинидии в полевых условиях.

Выражаем благодарность доктору сельскохозяйственных наук, директору Адлерской опытной станции ВИР Бойко Александру Петровичу за содействие успешному выполнению научно-исследовательской работы.

\section{Л ИТ Е РАТ УРА}

1. Food and Agriculture Organization of the United Nations. Value of agricultural production. Режим доступа: http://www.fao.org/faostat/en/\#data/QV. Без даты. 
2. Testolin P., Ferguson A.R. Kiwifruit (Actinidia spp.) production and marketing in Italy. New Zealand Journal of Crop and Horticultural Science, 2009, 37(1): 1-32 (doi: 10.1080/01140670909510246).

3. Park Y.S., Namiesnik J., Vearasilp K., Leontowicz H., Leontowicz M., Dinorah Barasch D., Nemirovski A., Trakhtenberg S., Gorinstein S. Bioactive compounds and the antioxidant capacity in new kiwi fruit cultivars. Food Chemistry, 2014, 165: 354-361 (doi: 10.1016/j.foodchem.2014.05.114).

4. Dimitrios B. Sources of natural phenolic antioxidants. Trends in Food Science \& Technology, 2006, 17(9): 505-512 (doi: 10.1016/j.tifs.2006.04.004).

5. Belitz H., Grosch W., Schieberle P. Fruits and fruit products. In: Food chemistry Springer. Springer, Berlin, Heidelberg, 2009: 807-861 (doi: 10.1007/978-3-540-69934-7).

6. Тутберидзе Ц.В., Грязев В.А. Формирование урожая и качество плодов киви на Черноморском побережье Краснодарского края. В сб.: Оптимизация породно-сортового состава и систем возделывания плодовых культур. Краснодар, 2003: 318-321.

7. Тарасенко В.С. Возделывание киви в России /Под ред. М.Н. Плехановой. СПб, 1999.

8. Айба Л.Я., Причко Т.Г., Вайнштейн Л.А. Киви - ценная субтропическая культура. В сб.: Современные аспекты теории и практики хранения и переработки плодово-ягодной продукиии. Краснодар, 2005: 109-113.

9. Айба Л.Я. Культура киви в Абхазии. Сухум, 2001.

10. Айба Л.Я., Губаз Э.Ш. Перспективные субтропические культуры в Абхазии. Сухум, 2017.

11. Salinger M.J., Kenny G.J. Climate and kiwifruit cv. «Hayward» 2. Regions in New Zealand suited for production. Journal of Crop and Horticultural Science, 1995, 23(2): 173-184 (doi: 10.1080/01140671.1995.9513884).

12. Bieniek A., Draga ska E., Pranckieties V. Assesment of climatic conditions for Actinidia arguta cultivation in north-eastern Poland. Zemdirbyste-Agriculture, 2016, 103(3): 311-318 (doi: 10.13080/z-a.2016.103.040).

13. Funda I.Y. Biological characteristics of kiwifruit orchard soils in Ordu/Turkey. Proc. International Soil Science Congress on «Soil science in International year of soils 2015» /E. Shein (ed.). Sochi, 2015: 169-173.

14. Green S.R., Sivakumaran S., van den Dijssel C., Mills T.M., Blattmann P., Snelgar W.P., Clearwater M.J., Judd M. A water and nitrogen budget for 'Hort16a' kiwifruit vines. Acta Hortic., 2007, 753: 527-535 (doi: 10.17660/ActaHortic.2007.753.69).

15. Morandi B., Losciale P., Manfrini L., Pierpaoli E., Zibordi M., Corelli Grappadelli L. Short-period changes in weather conditions affect xylem, but not phloem flows to young kiwifruit (Actinidia deliciosa) berries. Horticultural Science, 2012, 142: 74-83 (doi: 10.1016/j.scienta.2012.04.029).

16. Chaves M., Santos T., Souza C., Ortuco M., Rodrigues M., Lopes C., Maroco J., Pereira J. Deficit irrigation in grapevine improves water-use efficiency while controlling vigour and production quality. Annals of Applied Biology, 2007, 150(2): 237-252 (doi: 10.1111/j.17447348.2006.00123.x).

17. Cifre J., Bota J., Escalona J., Medrano H., Flexas J. Physiological tools for irrigation scheduling in grapevine (Vitis vinifera L.): An open gate to improve water-use efficiency? Agriculture, Ecosystems \& Environment, 2005, 106(2-3): 159-170 (doi: 10.1016/j.agee.2004.10.005).

18. Davies W.J., Wilkinson S., Loveys B. Stomatal control by chemical signalling and the exploitation of this mechanism to increase water use efficiency in agriculture. New Phytologist, 2002, 153(3): 449-460 (doi: 10.1046/j.0028-646X.2001.00345.x).

19. García-Tejero I.F., Durán-Zuazo V.H., Arriaga J., Muriel-Fernández J.L. Relationships between trunk- and fruit-diameter growths under deficit-irrigation programmes in orange trees. Horticultural Science, 2012, 133: 64-71 (doi: 10.1016/j.scienta.2011.10.022).

20. Kang S., Zhang J. Controlled alternate partial root-zone irrigation: its physiological consequences and impact on water use efficiency. Experimental Botany, 2004, 55(407): 2437-2446 (doi: 10.1093/jxb/erh249).

21. Intrigliolo D., Castel J. Performance of various water stress indicators for prediction of fruit size response to deficit irrigation in plum. Agricultural Water Management, 2012, 83(1-2): 173-180 (doi: 10.1016/j.agwat.2005.12.005).

22. Morandi B., Manfrini L., Losciale P., Zibordi M., Corelli Grappadelli L. Changes in vascular and transpiration flows affect the seasonal and daily growth of kiwifruit (Actinidia deliciosa) berry. Annals of Botany, 2010, 105(6): 913-923 (doi: 10.1093/aob/mcq070).

23. Torres-Ruiz J.M, Perulli G.D., Manfrini L., Zibordi M., Velasco G.L., Pierpaoli E. Anconelli S., Corelli-Grappadelli L., Morandi B. Time of irrigation affects vine water relations and the daily patterns of leaf gas exchanges and vascular flows to kiwifruit (Actinidia deliciosa Chev.). Agricultural Water Management, 2016, 166: 101-110 (doi: 10.1016/j.agwat.2015.12.012).

24. Мосияш А.С., Лугавцов А.М. Агроклиматическая характеристика Большого Сочи. Ростовна-Дону, 1967.

25. Беседина Т.Д., Тутберидзе Ц.В., Киселева Н.С. Особенности влияния агроклиматических факторов влажных субтропиков России на урожайность сорта Хейворд актинидии деликатесной. Садоводство и виноградарство, 2020, 5: 42-46 (doi: 10.31676/0235-2591-2020-5-42-46).

26. Беседина Т.Д., Тутберидзе Ц.В., Тория Г.Б. Водный режим влажных субтропиков России и орошение актинидии деликатесной (Actinidia deliciosa (A. Cher.) Liang. Et. Ferg.). В сб.: 
Субтропическое и декоративное садоводство. Сочи, 2018, 66: 135-144 (doi: 10.31360/22253068-2018-66).

27. Филиппов Л.А. Рефрактометрический метод и принципы диагностирования сроков полива чайных плантаций. В сб.: Водный режим и орошение плодовых и субтропических культур в горных условиях. Сочи, 1975, 21: 102-121.

28. Доспехов Б.А. Методика полевого опыта (с основами статистической обработки результатов исследований). М., 1985.

29. Пиньковский М.Д., Ивонин В.М., Самсонов С.Д., Ширяева Н.В., Егошин А.В. Научное обоснование ГИС «Сочинский национальный парк» /Под ред. В.М. Ивонина. Сочи, 2011.

30. Жученко А.А. Адаптивная стратегия устойчивого развития сельского хозяйства России в ХХІ столетии. Теория и практика. Том II. М., 2009-2011.

31. Navarro J.M., Pérez-Pérez J.G., Romero P., Botha P. Analysis of the changes in quality in mandarin fruit, produced by deficit irrigation treatments. Food Chemistry, 2010, 119(4): 15911596 (doi: 10.1016/j.foodchem.2009.09.048).

32. Kusakabe A., Contreras-Barragan B.A., Simpson C.R., Enciso J.M., Nelson S.D., Melgar J.C. Application of partial rootzone drying to improve irrigation water use efficiency in grapefruit trees. Agricultural Water Management, 2016, 178: 66-75 (doi: 10.1016/j.agwat.2016.09.012).

33. Naor A. Irrigation scheduling and evaluation of tree water status in deciduous orchards. In: Horticultural reviews /J. Janick (ed.). John Wiley \& Sons, Inc., Oxford, 2006, 32: 111-165 (doi: 10.1002/9780470767986.ch3).

34. Prado A.K., Machado E.C., Medina C.L., Machado D., Mazzafera P. Florescimento e frutificação em laranjeiras 'Valencia' com diferentes cargas de frutos e submetidas ou пго a irrigação. Bragantia, 2007, 66: 173-182 (doi: 10.1590/S0006-87052007000200001).

35. Клемешова К.В., Белоус О.Г. Водообеспеченность растений актинидии сладкой в субтропиках России. Вестник Российской академии сельскохозяйственных наук, 2009, 6: 55-56.

36. Гончарова Э.А. Агрометеорологическая составляющая плодоношения растений в южных регионах России (система регуляции и прогнозирования). Мат. Межд. науч.-практ. конф. «Научное обеспечение устойчивого развития плодоводства и декоративного садоводства». Сочи, 2019: 105-109.

37. Ward C., Courtney D. Chapter One - Kiwifruit: taking its place in the global fruit bowl. In: $A d$ vances in food and nutrition research /M. Boland, P.J. Moughan (eds.). Academic Press, 2013, 68: 1-14 (doi: 10.1016/B978-0-12-394294-4.00001-8).

38. Golden times return for kiwifruit trade. NZ Herald. 26 May 2014. Режим доступа: https://www.nzherald.co.nz/business/golden-times-return-for-kiwifruit-trade/Y7ASXIO2VTORC7ILBYEDHFJ3XY/. Дата обращения: 22.10.2021

39. Stirk B. Growing kiwifruit (PDF). Pacific Northwest Extension Publishing, PNW 507, 2005. Режим доступа: https://catalog.extension.oregonstate.edu/pnw507. Дата обращения: 22.10.2021.

40. Boland M. Chapter Four - Kiwifruit proteins and enzymes: actinidin and other significant proteins. In: Advances in food and nutrition research /M. Boland, P.J. Moughan (eds.). Academic Press, 2013, 68: 59-80 (doi: 10.1016/B978-0-12-394294-4.00004-3).

41. Bieniek A., Draga ska E. Content of macroelements in fruits of Ukrainian cultivars of hardy kiwifruit and actinidia charta depending on the weather conditions during the phenological phases. Journal of Elementology, 2013, 18(1): 23-38 (doi: 10.5601/jelem.2013.18.1.02).

42. Horák M. Quality parameters of kiwiberries grown in the Czech Republic. Acta Horticulturae et Regiotecturae, 2020, 1: 17-20 (doi: 10.2478/ahr-2020-0005).

43. Chauhan N., Chandel J.S. Growth, productivity, leaf nutrient contents and water-use efficiency of kiwifruit (Actinidia deliciosa) under drip and basin irrigation system. Agricultural Sciences, 2010, 80(7): 584-587.

44. Snelgar W.P., Hall A.J., Ferguson A.R., Blattmann P. Temperature influences growth and maturation of fruit on 'Hawyard' kiwifruit vines. Functional Plant Biology, 2005, 32(7): 631-642 (doi: 10.1071/FP05062).

45. Figiel-Kroczyńska M., Ochmian I., Lachowicz S., Krupa-Małkiewicz M., Wrybel J., Gamrat R. Actinidia (mini kiwi) fruit quality in relation to summer cutting. Agronomy, 2021, 11(5): 964 (doi: 10.3390/agronomy11050964).

46. Holzapfel E., Merino R., Marico M., Matta R. Water production functions in kiwi. Irrig. Sci., 2000, 19: 73-79 (doi: 10.1007/s002710050003).

47. Miller S.A., Smith G.S., Boldingh H.L., Jonansson A. Effects of water stress on fruit quality attributes of kiwifruit. Annals of Botany, 1998, 81(1): 73-81 (doi: 10.1006/anbo.1997.0537).

48. Якушев В.П., Якушев В.В., Баденко В.Л., Матвеенко Д.А., Чесноков Ю.В. Оперативное и долгосрочное прогнозирование продуктивности посевов на основе массовых расчетов имитационной модели агроэкосистемы в геоинформационной среде (обзор). Сельскохозяйственная биология, 2020, 55(3): 451-467 (doi: 10.15389/agrobiology.2020.3.451rus).

ФГБУН ФИЦ Субтропический научный центр РАН, 354002 Россия, г. Сочи, ул. Яна Фабрициуса, 2/28, e-mail: supk@vniisubtrop.ru $\bowtie$, besedinatd21@rambler.ru,

Поступила в редакцию e-mail: supk@vniisubtr

9 июня 2021 года 


\title{
ON SPECIFIC INFLUENCE OF THE AGROECOLOGICAL CONDITIONS OF HUMID SUBTROPICS OF RUSSIA ON PRODUCTIVE POTENTIAL OF Actinida deliciosa (kiwifruit)
}

\author{
T.D. Besedina, Ts.V. Tutberidze ${ }^{\bowtie}$, N.S. Kiseleva
}

Federal Research Centre the Subtropical Scientific Centre RAS, 2/28, ul. Yana Fabriciusa, Sochi, 354002 Russia, e-mail supk@vniisubtrop.ru ( $₫$ corresponding author), besedinatd21@rambler.ru, nskiselyeva_05@mail.ru ORCID:

Besedina T.D. orcid.org/0000-0001-5587-749X

Tutberidze Ts.V. orcid.org/0000-0002-1486-0787

Kiseleva N.S. orcid.org/0000-0001-8655-6381

The authors declare no conflict of interests

Acknowledgements:

We express our gratitude to the DSci in agriculture, Director of the Adler Experimental Station VIR A.P. Boyko for his assistance in the successful implementation of this research work.

The work was carried out within the framework of the theme 0492-2021-0007 "To identify the base mechanisms of adaptation of agricultural crops, ornamental plants, and artificially created biocenoses to stress factors of various nature and to study the patterns of their manifestation to develop methods for stabilizing the production process and preserving decorativeness".

Received June 9, 2021

doi: 10.15389/agrobiology.2021.5.999eng

\section{Abstract}

Actinida deliciosa (kiwi), recognized for its delicious taste and health-promoting properties, is successfully cultivated in the subtropical regions of the planet. The peculiar climate of the humid subtropics of Russia influences the actinidia plants, in particular, the onset of phenological phases. During fruit formation (June-September), actinidia plants need irrigation depending on the amount of precipitation and temperature conditions. Here we show that in the humid subtropics of Russia, the periods of kiwi fruit formation differ from year to year for precipitations, which coincides with the moisture deficit in the soil. For the first time, we have developed a simple physiological indicator to promptly estimate water status of kiwi plants for timely irrigation based on the cell sap concentration in petioles which correlates with soil moisture in the $0-60 \mathrm{~cm}$ layer. Purpose of this work is to determine the complex of agroecological factors affecting the moisture supply and productivity of $A$, deliciosa in the changing weather conditions of the humid subtropics of Russia. The study was performed on lateripening cv. Hayward planted in 1988 (a $5 \times 4 \mathrm{~m}$ scheme, the total site area of 5.5 ha, three-tiered palmette shaping; the Adler experimental station of the Vavilov FRC All-Russian Institute of Plant Genetic Resources, Krasnodar Territory, 2016-2020). The average daily and maximum temperatures were recorded from May to October, the http://www.pogodaiklimat.ru data were used for precipitation. Moisture content of the soil, taken in 10-cm layers along the depth of the root layer $(0-60 \mathrm{~cm})$, was measured by the thermostat-weight method. The concentration of cell sap (CCS, \%) in the leaves was measured refractometrically from May to September in ten plants (for 3 decades of each month). The yield of each bush ( $n=30$ in total, three replicates) was recorded. Annually, the average weight of a berry was determined using 100 berries. The weather conditions of the growing seasons significantly differed and showed abnormal precipitations and extreme temperatures (above $30{ }^{\circ} \mathrm{C}$ ), affecting the water regime of plants and productivity. In May-June 2016-2020, the water content of leaf tissues was high (CCS 4.96-5.25\%), therefore, during the periods of budding, flowering, and fruit setting, the moisture supply of the plantings was optimal. In August, fruits began to grow actively and the initiation of the next-year generative organs occurred. However, high insolation and the temperature rise above $30{ }^{\circ} \mathrm{C}$ increased evaporations, while the atmospheric precipitations were minimal. The soil moisture reserves from May to October were optimal and ranged from 80 to $90 \%$ of the least moisture capacity over the entire depth of the soil profile. However, the CCS increased from mid-September and exceeded $10 \%$ at the end of the month despite the complete soil saturation with moisture. Tension in the environment and the peak of physiological processes caused water deficit in the leaves up to the CCS $>7 \%$ which irrigation still could level. At the end of August or at the beginning of September (depending on weather conditions), the CCS steadily rose above $8 \%$, regardless of irrigation. During this period, a redistribution of water fractions from bound to free ecologically active form occurs. The earlier the transition of water and assimilation from the leaves of kiwi plants to fruits begins, the higher their weight and yield. Thus, our findings show that in the humid subtropics of Russia, the studied agroecological factors have the greatest effect on the water regime and performance of A. deliciosa cv. Hayward plants during the period of fruit formation (in August-September).

Keywords: actinidia (kiwi), cv. Hayward, water regime, productivity, heat supply, moisture supply, humid subtropics. 